\title{
An Eighteenth Century Recall of Judges
}

$\mathrm{T}$

HE case of the miller Arnold as detailed by Carlyle in his "Frederick the Great" is an interesting story of a judicial recall. Arnold and his predecessors held a mill, called Krebsmuhle, Crabmill, on a certain stream in Prussia from Graf von Schmettau. A certain Freiherr von Gersdorf on the same stream diverted water for a fishpond, the result of which was that Arnold was unable to run his mill and defaulted in his payments to his landlord. The latter finally sued for his rent, with the result that Arnold was ousted from his mill. The case went through all the courts of the province of Cüstrin, and finally was referred by the King to the Kammergericht in Berlin. This tribunal affirmed the action of the other courts. Carlyle proceeds:

"It was Friday roth December 1779 before Friedrich got this fine bit of news; Saturday Irth, before he authentically saw their Sentence. He is lying miserably ill of gout in the Schloss of Berlin; and I suppose, since his Father, of blessed memory, took cudgel to certain Judges and knocked out teeth from them, and broke the judicial crowns, nobody in that Schloss has been in such humour against men of Law. 'Attend me here at 2 P. M. with the Three Raths who signed in Arnold's Case:' Saturday, about II A. M., Chancellor Fürst receives this command; gets Rannsleben, and two others, Friedel, Graun,--and there occurred such a sceneBut it will be better to let Rannsleben himself tell the story; who has left an Autobiogrcphy, punctually correct, to all appearance, but except this alone notable passage of it, still unpublished, and like to continue so. . . . .

"'At I o'clock I drove to the Grand-Chancellor's, where I found the Raths Friedel and Graun already arrived. The Chancellor, old Fürst, instructed us as to what we had to do when we came before the King. And then, towards 20 'clock, he took us in his carriage to the Palace. We entered the room immediately at the end of the Great Hall. Here was found a heyduc (tall porter), by whom the Chancellor announced to the King that we were here. Heyduc soon came back to inquire, Whether the Cabinets-Rath Stellter, a Secretary or Short-hand writer of his 
Majesty's, had arrived yet; and whether we (zee, what a doubt) were Privy Councillors. We were then shortly after shown in to the King. We passed through three rooms, the second of which was that in which stands the Confidenz Tafel (Table that goes by pulleys through the floor, and comes up refurnished, when you wish to be specially private with your friends). In the fourth, a small room with one window, was the King. The Chancellor walked first; I followed him close; behind me came the Rath Friedel, and then Graun. Some way within, opposite the door, stood a screen; with our backs to this, the King-ward side of this, we ranged ourselves, -in respectful row of Four, Fürst at the inward end of us (right or left is no matter). The King sat in the middle of the room, so that he could look pointblank at us; he sat with his back to the chimney, in which there was a fire burning. He had on a worn hat, of the clerical shape (old-military in fact, not a shovel at all); cassaquin, short dressing-gown, of red-brown (mordore) velvet; black breeches, and boots which came quite up over the knee. His hair was not dressed. Three little benchlets or stools, covered with green cloth, stood before him, on which he had his feet lying (terribly ill of gout). In his lap he had a sort of muff, with one of his hands in it, which seemed to be giving him great pain. In the other hand he held our Sentence on the Arnold Case. He lay reclining (lag) in an easy chair; at his left stood a table, with various papers on it,and two gold snuff-boxes, richly set with brilliants, from which he kept taking snuff now and then.

"Besides us, there was present in the room the Cabinets-Rath Stellter (of the short-hand), who stood at a desk, and was getting ready for writing. The King looked at us, saying 'Come nearer.' Whereupon we advanced another step, and were now within less than two steps of him. He addressed himself to us three Raths, taking no notice at all of the Grand-Chancellor:

King. "Is it you who drew-up the judgment in the Arnold case?"

$W e$ (especially I, with a bow). "Yea."

" "The King then turned to the Rath Friedel (to Friedel, as the central figure of the Three, perhaps as the portliest, though poor Friedel, except signing, had little cognisance of the thing, in which not he but Rannsleben was to have been spokesman), and addressed to Friedel those questions, of which, with their answers, 
there is Protocol published, under Royal authority, in the Berlin newspapers of December 14th, I779; Short-hand Stellter taking down what was said,-quite accurately, testifies Rannsleben. From Stellter (that is to say from the 'Protocol' just mentioned), or from Stellter and Rannsleben together, we continue the Dialogue:

King to Friedel (in the tone of a Rhadamanthus suffering from gout). "To give sentence against a Peasant from whom you have taken wagon, plough and everything that enables him to get his living, and to pay his rent and taxes: is that a thing that can be done?"

Friedel (and the two Mutes, bowing). "No."

King. "May a Miller who has no water, and consequently cannot grind, and therefore, not earn anything, have his mill taken from him, on account of his not having paid his rent: is that just?"

Friedel (and Mutes as aforesaid). "No."

King. "But here now is a Nobleman, wishing to make a Fishpond : to get more water for his Pond, he has a ditch dug, to draw into it the water from a small stream which drives a water-mill. Thereby the Miller loses his water, and cannot grind; or, at most, can only grind in the spring for the space of a fortnight, and late in the autumn, perhaps another fortnight. Yet, in spite of all this, it is pretended that the Miller shall pay his rent quite the same as at the time when he had full water for his mill. Of course, he cannot pay his rent; his incomings are gone. And what does the Cüstrin Court of Justice do? It orders the mill to be sold, that the Nobleman may have his rent. And the Berlin Tribunal"Chancellor Fürst, standing painfully mute, unspoken to, unnoticed hitherto, more like a broomstick than a Chancellor, ventures to strike in with a syllable of emendation, a small correction, of these words "Berlin Tribunal"-

Furst (suggestively). "Kammergericht" (inildly suggestive, and perhaps with something in his tone which means, "I am not a broomstick"): "Kammergericht!"

King (to short-hand Stellter). "Kammergerichts-Tribunal:"(then to Fürst) "Go you, Sir, about your business, on the instant! Your Successor is appointed; with you I have nothing more to do. Disappear."-_'Ordered,' says Official Rannsleben, 'ordered the Grand-Chancellor, in very severe terms, To be gone.' telling him that his Successor was already appointed. Which order Herr von Fürst, without saying a word, hastily obeyed, passing in front of 
us three, with the utmost speed.' In front,-screen, I suppose, not having room behind it,- and altogether vanishes from Friedrich's History; all but some ghost of him (so we may term it), which reappears for an instant once.

King (continues to Friedel, not in a lower tone probably) :"the Kammergerichts-Tribunal confirms the same. That is highly unjust; and such Sentence is altogether contrary to his Majesty's landsfatherly intentions:-my name" (you give it, 'In the King's. Name,' forsooth) "cruelly abused!"

"The King's desire always is and was, That everybody, be he high or low, rich or poor, get prompt justice; and that, without regard of person or rank, no subject of his fail at any time of impartial right and protection from his Courts of Law.

" 'Wherefore, with respect to this most unjust Sentence against the Miller Arnold of the Pommerzig Crabmill, pronounced in the Neumark, and confirmed here in Berlin, his Majesty will establish an emphatic example (ein nachdrueckliches Exempel statuiren); to the end that all Courts of Justice, in all the King's Provinces, may take warning thereby, and not commit the like glaring unjust acts. For, let them bear in mind, That the least peasant, yea, what is still more, that even a beggar, is, no less than his Majesty, a human being, and one to whom due justice must be meted out. All men being equal before the Law, if it is a prince complaining against a peasant, or vice versa, the prince is the same as the peasant before the Law ; and, on such occasions, pure justice must have its course, without regard of person: Let the Law-Courts, in all the Provinces, take this for their rule. And whenever they do not carry out justice in a straightforward manner, without any regard of person and rank, but put aside natural fairness,--then they shall have to answer his Majesty for it (sollen sie es mit Seiner Koeniglichen Majestat zu thun kriegen.) For a Court of Law doing injustice is more dangerous and pernicious than a band of thieves: against these one can protect oneself; but against rogues who make use of the cloak of justice to accomplish their evil passions, against such no man can guard himself. These are worse than the greatest knaves the world contains, and deserve double punishment.

"For the rest, be it also known to the various Courts of Justice, That his Majesty has appointed a new Grand-Chancellor. Fürst dismissed. Yet his Majesty will not the less look sharply with his own eyes after the Law-proceedings in all the Provinces; and he 
commands you-that is, all the Law-courts-urgently herewith: Firstly,-which is also lastly,-To proceed to deal equally with all people seeking justice, be it prince or peasant; for, there, all must be alike. However, if his Majesty, at any time hereafter, come upon a fault committed in this regard, the guilty Courts can now imagine beforehand how they will be punished with rigour, President as well as Raths, who shall have delivered a judgment so wicked and openly opposed to justice. Which all Colleges of Justice in all his Majesty's Provinces are particularly to take notice of.

Mem. By his Majesty's special command, measures are taken that this Protocol be inserted in all the Berlin Journals."

"The remainder of Rannsleben's Narrative is beautifully brief and significant.- 'We had hardly left the room, said he supra, when the King followed us, lame as he was, with a fulminant "Wait there." Rannsleben continues: 'Shortly after came an Aide-de-Camp, who took us in a carriage to the common Town-prison, the Kalandshof; here two Corporals and two Privates were sent to guard us. On the I 3 th December I779, third day of our arrest, a Cabinet-Order was published to us, by which the King had appointed a Commission of Inquiry; but had, at the same time, commanded beforehand that the Sentence should not be less than a year's confinement in a fortress, dismissal from office, and payment of compensation to the Arnold people for the losses they had sustained. Which certainly was a bad outlook for us.

"Precisely the same has befallen our Brethren of Cüstrin; all suddenly packed into Prison, just while reading our Approval of them; - there they sit, their Sentence to be like ours. Our arrest in the Kalandshof lasted from IIth December, I779 till 5th January I780, three weeks and three days, - when (with Two Exceptions, to be noted presently) we were all, Kammergerichters and Cüstriners alike, transferred to Spandau."

The result of the recall is detailed by Carlyle in a quotation from an account given by an eye witness.

"During the days that followed I often crossed in the forenoon, the Esplanade in front of the Palace (Schlossplatz), at that side where the King's apartments were; the'same which his Royal Highness, the Crown Prince now (I833) occupies. I remember that here, on that part of the Esplanade which was 
directly under Friedrich's windows, there stood constantly numbers of Peasants, not ten or twelve, but as many as a hundred at a time; all with petitions in their hands, which they were holding up towards the window shouting, "Please his Majesty to look at these; we have been still worse treated than the Arnolds!" And indeed, I have understood the Law Courts for some time after, found great difficulty to assert their authority-the parties against whom judgment went, taking refuge in the Arnold precedent, and appealing direct to the King."

Even Frederick found opposition in carrying out his arbitrary decree concerning the chancellor and the Judges. Minister von Zedlitz refused to pronounce the sentence. The King writes Zedlitz as follows:

"Your Report of the 2oth instant in regard to Judgment on the arrested Raths has been received. But do you thimk I don't understand your Advocate fellows and their quirks; or how they can polish-up a bad cause, and by their hyperboles exaggerate or extenuate as they find fit? The Goose-quill class (Federzeug) can't look at facts. When Soldiers set to investigate anything, on an order given, they go the straight way to the kernel of the matter; upon which, plenty of objections from the Goose-quill people!-But you may assure yourself I give more belief to an honest Officer, who has honour in the heart of him, than to all your Advocates and sentences. I perceive well they are themselves afraid, and don't want to see any of their fellows punished.

"If, therefore, you will not obey my Order, I shall take another in your place who will; for depart from it I will not. You may tell them that. And know, for your part, that such miserable jargon (miserabel Styl) makes not the smallest impression on me. Hereby, then, you are to guide yourself; and merely say whether you will follow my Order or not; for I will in no wise fall away from it. I am your well-affectioned King,-FrIEDRICH."

Von Zedlitz continuing his refusal, the King himself pronounced the sentence. With the exception of one of the Cüstrin judges who had dissented, and of Rannsleben, who had acted with impartiality, the other judicial officers are "one and all dismissed from office (cassirt), and condemned to one year's Fortress Arrest. Furthermore, they shall pay to Arnold the value of his Mill, and make good to him, out of their own pockets, all the loss and damage he has suffered in this business." 
The sequel of the story is found in the reign of Frederick's successor, Frederick William II. The sentence of Frederick was reversed and Arnold ordered to pay back the money paid him by the condemned judges, and also the purchase money of the mill, if he desired to keep it. "All which moneys, however, his majesty Friedrich Wilhelm II, Friedrich's successor, to have done with the matter, handsomely paid out of his own pocket: the handsome way of ending it." 